\title{
Glycogen in Liver: Characteristics and Biosynthesis
}

\author{
肝グリコゲニン: その性質と生合成
}

\begin{abstract}
1,* Gannon, Mary C.; and "Nuttall, Frank Q.
Metabolic Research Laboratory and the Section of Endocrinology, Metabolism and Nutrition, Minneapolis Veterans Affairs Medical Center and the Departments of Medicine" and Food Science \& Nutrition' ,University of Minnesota Minneapolis, MN 55417 USA, FAX: 1-612-725-2273, E-mail: ganno004@ maroon.tc.umn.edu
\end{abstract}

Key Words: glycogen, glycogenin, liver, proteoglycan

\begin{abstract}
It generally is agreed that initiation of a glycogen molecule occurs through the addition of a linear array of glucose molecules to a protein referred to as glycogenin. The addition of glucosyl units is catalyzed by glycogenin itself. The product is then branched and expanded by other enzymes. This process has been studied best in skeletal muscle. In skeletal muscle, all of the glycogenin is incorporated into glycogen molecules (1) The glycogen molecules also are all presumed to be proteoglycans.

In liver, glycogenin is free, i.e., not incorporated into a proteoglycogen molecule in the fasted state and it becomes incorporated into a glycogen molecule only later in the feeding phase. Furthermore, preliminary data suggest that most of the glycogen molecules are not proteoglycans but rather are independent of glycogenin. Thus, the character and biosynthesis of glycogen in liver appears to be much more complex than in skeletal muscle. Regulation of the various forms of glycogen also is likely to be complex.
\end{abstract}

\section{A. Introduction}

Glycogen is the storage form of glucose in animals. It is a highly branched structure composed of thousands of glucose molecules attached to each other in an $\alpha-1,4$ glucosidic linkage with branch points consisting of $\alpha-1,6$ linkages. The external branches on the surface of the glycogen molecule are estimated to consist of a linear array of 12-14 glucose molecules. The internal branches are 4-6 glycosyl units in length.

The molecular weight (MW) of glycogen is polydisperse. Particles with an estimated MW up to 1 billion have been reported on gradient density analysis and by electron microscopy (2). However, these very large particles most likely represent aggregates or assemblies of individual glycogen molecules. The largest individual glycogen molecule appears to have a MW of $\sim 8$ million and to contain 50,000 glucose molecules arranged in 12 tiers of branches $(2,3)$. Why there is a limit in glycogen molecular weight is uncertain. It has been attributed to steric hindrance (4).
要 約

グリコーゲン分子の合成は、glycogenin と呼ばれるタンパ ク質へグルコース残基が線状に付加されることによって開始さ れることが一般に受け入れられている。グルコース残基の付加 はglycogenin 自身により触媒され、それによって生じた産物は 他の酵素によって枝付けされ伸長される。この過程は骨格筋に おいて最もよく研究されている。骨格筋ではすべての glycogenin 分子がグリコーゲンに取り込まれた形で存在する (1)。したがって、グリコーゲン分子はすべてプロテオグリカン であると考えられている。

肝臟においては glycogenin は遊離の状態で存在する。すな わち絶食状態では glycogenin はプロテオグリコーゲン分子に取 り込まれず、その後の給飭によってのみ取り込まれる。さらに、 大部分のグリコーゲン分子はプロテオグリカンではなく、 glycogenin とは独立に存在することが予備的な実験により示さ れている。したがって、肝臓におけるグリコーゲンの性質と生 合成過程は骨格筋におけるそれらよりもずっと複雑であるらし い。グリコーゲンの多様な形態の制御も複雑であるようだ。

A. はじめに

グリコーゲンは動物におけるグルコースの貯蔵形態であ る。その分子は高度に分岐した構造を持っており、数千のグル コース残基が $\alpha-1,4-$ グルコシド結合で連結され、それらが $\alpha$ 1,6-グルコシド結合で枝分かれしている。グリコーゲン分子の 表面の外部鎖は $12 \sim 14$ グルコースからなり、内部鎖は〜4-6グ ルコースからなる。

グリコーゲンの分子量は多様である。密度勾配分析や電子 顕微鏡観察により、分子量 10 億に及ぶ粒子が報告されている (2)。しかし、これらの非常に大きな粒子はおそらくグリコーゲ ン分子の会合体、または集合体であろう。単独のグリコーゲン 分子で最大のものは分子量 800 万程度で、 50,000 グルコース残 基が 12 層の分岐単位に配列されている (2、3)。なぜグリコーゲ ンの分子量に上限があるのかは不明確であるが、立体障害のた めであるとされている (4)。 
In spite of the very large size of some of these molecules, each begins with a single glucose molecule which is referred to as the reducing end because unless it is derivatized to protein or another substance, it has a free aldehyde group which is chemically reactive. Thus, theoretically a glycogen molecule could consist of anywhere from less than 100 glycosyl units to several thousand.

As currently defined, glycogen consists of those structures which after potassium hydroxide $(\mathrm{KOH})$ digestion of tissue are precipitable by a $66 \%$ ethanol $(\mathrm{EtOH})$ solution. This is the method against which other extraction methods are compared (5). This procedure, however, is known to degrade glycogen particles. Primarily it affects the association of the glycogen molecules, probably through formation of isosaccharinic acid groups, although some degradation of individual molecules also occurs (6). In order to isolate intact glycogen other methods must be used. A number of these have been described $(2,3,7-9)$. Whether ethanol also will precipitate small nascent or immature small glycogen molecules, particularly if they are attached to protein is uncertain, although ethanol has been reported to precipitate even oligosaccharides (10). To our knowledge, this issue has not been rigorously evaluated. Nevertheless, ethanol precipitation currently is considered the best method for isolating and quantifying the total amount of glycogen present in a tissue.

\section{B. Expansion of Nascent Glycogen or Oligosaccharides to Mature Glycogen}

Small glycogen molecules or even malto-oligosaccharides are substrate for glycogen synthase which adds glucosyl units to the non-reducing ends of the branches of glycogen or the non-reducing end of oligosaccharides in an $\alpha-1,4$ linkage. UDP-glucose is the glucosyl donor. Once the chain is elongated to 12-14 units, branching enzyme removes a linear chain of 4-6 glucose molecules and inserts it in an $\alpha-1,6$ linkage forming a branch point. This chain also then may be elongated by the action of glycogen synthase.

We have purified the branching enzyme from rat liver and have found the activity to be 150 -fold greater than that of the synthase (unpublished), confirming that it is the synthase which is rate limiting in expansion of the nascent glycogen molecule to a mature glycogen molecule.

Our laboratory also has shown that specific isozymes of synthase are present in liver and skeletal muscle (11-14). Both isozymes are regulated by a complex dephosphorylation-phosphorylation mechanism which also interacts in a complex fashion with allosteric effectors $(15,16)$. However, the liver enzyme is more highly phosphorylated, and its physiological regulation is different than that of skeletal muscle (15). Recently we have cloned and sequenced the gene for the human liver enzyme (11), have localized the gene to chromosome 12
このようにグリコーゲン分子のあるものは特に高分子であ るが、タンパクや他の物質と結合しているのでない限り、おの おのの分子は還元性末端という単一のグルコース分子からはじ まっている。その末端は遊離のアルデヒド基を持っており、化 学的に反応性が高い。このように、理論的にはグリコーゲン分 子は 100 グルコース残基以下のものから数千グルコース残基に 至るものまでどの大きさのものも存在しうる。

現在定義されているところでは、グリコーゲンは、組織を 水酸化カリウム $(\mathrm{KOH})$ で消化した後、66\%エ夕ノールで沈殿 する構造体からなる。この方法は、他の抽出方法に匹敵するも のである (5) が、グリコーゲン顆粒を分解することが知られて いる。いくらかは、個々の分子の分解も起こるが、主に、たぶ んイソサッカリン酸基の形成によりグリコーゲン分子の会合に 影響を及ばすのである(6)。完全な状態のグリコーゲンを単離す るためには、他の方法を用いなければならず、そのための多く の方法が報告されている (2、3、7-9)。エタノールはオリゴ糖で さえも沈殿させることが報告されているが (10)、合成途中の、 あるいは未熟な低分子グリコーゲンを沈殿させるかどうかは、 特にそれらがタンパク質と結合している場合はっきりしない。 私たちの知る限りでは、この問題は厳密には調べられていない。 それでも、エタノール沈殿は現在のところ組織中のグリコーゲ ンを単離し定量するための最善の方法と考えられている。

\section{B. 合成途中のグリコーゲン、あるいはオリゴ糖の成熟グリコー ゲンへの伸長}

低分子グリコーゲン、あるいはマルトオリゴ糖でも glycogen synthaseの基質となる。この酵素は、グリコーゲンの枝の非 還元末端やオリゴ糖の非還元末端に $\alpha-1,4$-結合でグルコシル基 を付加する酵素であり、UDP-グルコースがグルコシル基供与体 となる。いったん、鎖が12-14グルコシル残基分まで伸びると、 branching enzymeが 4-6グルコース残基の鎖を取り除き、それを 転移させて $\alpha-1,6-$ 結合の分岐点を作る。そして、その鎖も glycogen synthase の作用により伸ばされ得る。

私たちはラット肝臓の branching enzyme を精製し、その活 性はsynthaseよりも150倍も多く存在することを見いだした (未 発表)。このことは、新生グリコーゲンが成熟グリコーゲンへ伸 長する過程を律速しているのが synthase であることを確認する ものであった。

私たちの研究室では、肝臓と骨格筋に特異的な synthase $ア$ イソザイムが存在することを示してきた(11-14)。両アイソザイ ムともに、複雑な脱りン酸化 - リン酸化機構による制御を受け ており、その機構もアロステリックエフェクターと複雑に相互 作用する (15、16)。しかし、肝臟の酵素はより高度にリン酸化 されており、その生理学的な制御は骨格筋におけるそれと異 なっている (15)。最近私たちはヒト肝臟の本酵素遺伝子のク ローン化と塩基配列決定を行うとともに (11)、本遺伝子が12番 
(17) and have begun site-directed mutagenesis studies in order to probe the structural basis for its regulation. The regulation of synthase has been a major interest in our laboratory for many years.

Although synthase and the branching enzyme activities can explain the expansion of small or nascent glycogen molecules, they are not likely to explain the de novo synthesis of glycogen molecules. Nevertheless, this is a theoretical possibility. The minimal length of a malto-oligosaccharide chain that will serve as a substrate for glycogen synthase was reported to be 1 to 4 glucose units (maltotetraose) (18-20). However, the affinity was much less than when acting on the branches of glycogen and contamination of the synthase preparation with glycogenin cannot be ruled out.

\section{Initiation of the New Glycogen Molecule}

In 1934 Willstätter and Rohdewald (9)extracted tissues with hot water. A soluble fraction was obtained, referred to as lyo-glycogen. From the insoluble material a second smaller fraction was obtained after proteolytic enzyme treatment or alkaline digestion which they referred to as desmo-glycogen. They believed the latter form of glycogen to be less soluble due to combination with protein. They also reported that it was lyoglycogen that changed with feeding. Others referred to the desmo-glycogen fraction as "residual" glycogen (5).

Whether there were two forms of glycogen, one trichloroacetic acid (TCA) precipitable and one not, and whether their metabolism was regulated differently, resulted in numerous publications [reviewed in reference (5)] and became a contentious issue that has never been completely resolved. In a review, Stetten and Stetten (5), as well as Roe et al. (21) suggested that there were many forms of glycogen present in cells and that the classification into an easily extractable form and a more difficult to extract form was somewhat arbitrary. Until recently there has been little interest in pursuing the possibility of different forms being present or the possibility that they may be metabolically important and regulated differently.

Stetten and Stetten (5) also suggested that the protein associated with glycogen as fractionated was due both to a nonspecific binding of proteins and to non-covalent attachment of the enzymes concerned with glycogen metabolism. Later, Fischer and Stetten (22) reported that protein made up 40$50 \%$ of the glycogen as isolated from skeletal muscle. They and subsequently Cohen (23) attributed the protein to non-covalently bound enzymes important in glycogen metabolism. These included glycogen phosphorylase, phosphorylase kinase, glycogen synthase, synthase kinase 2, and cAMP kinase. Small amounts of other enzymes and sarcoplasmic reticulum also were present. That the protein associated with glycogen represented non-covalently bound proteins, primarily glycogen associated enzymes, was the accepted explanation for the small
染色体に存在していることを示した (17)。また、その制御にお ける構造的な基本原理を探るために部位特異的変異操作を用い た研究を開始した。Synthaseの制御は私たちの研究室における 長年の主要な興味の対象である。

低分子の、あるいは合成途中のグリコーゲンの伸長は、 synthase と branching enzymeの活性によって説明することができ るが、それらの活性によってグリコーゲン分子の新規合成を説 明することはできそうにない。それでも理論上は可能性がある。 Glycogen synthase の基質になりうる最小のマルトオリゴ糖は 1 から 4 グルコース残基 (マルトテトラオース)功なると報告さ れている(18-20)。しかし、その場合の親和性はグリコーゲンの 枝に作用する場合と比べるとずっと低いし、使われた synthase 標品にglycogenin が混入していた可能性も否定できない。

\section{C. 新しいグリコーゲン分子の合成開始反応}

1934 年にWillstäter と Rohdewald (9) は組織を熱水抽出し て可溶性の画分を得、これを溶解型グリコーゲンと呼んだ。不 溶性の画分からは、タンパク分解酵素処理やアルカリ分解の後 に第2のより少量の画分を得て、これを結合型グリコーゲンと 呼んだ。彼らは、後者のグリコーゲンは、タンパク質と結合し ているために溶解しにくいのだと考え、また溶解型グリコーゲ ンが給餌によって変化したものであると報告している。別の研 究者は、結合型グリコーゲン画分を“残留”グリコーゲンと呼ん でいる (5)。

トリクロロ酶酸 (TCA) で沈殿するものと沈殿しないもの の 2 種類のグリコーゲン形態があるのかどうか、またそれらの 代謝が別々に制御されているのかどうかについては、多くの報 告があり[文献 (5) に総説がある]、論争の的になっているが完 全には解決されていない。ある総説において、Stetten と Stetten (5) は、細胞内には多くの形態のグリコーゲンが存在すること、 それらの易抽出形態と難抽出形態への分類はやや恣意的になる ということを示している。Roeら (21) も同様の示唆を行ってい る。最近までこの異なった形態が存在する可能性、あるいはそ れらの代謝における重要性や別個に制御されている可能性を追 求することにはほとんど興味が払われていなかった。

Stetten と Stetten (5) は、分画されたグリコーゲンに結合し ているタンパク質には非特異的に結合しているものと非共有結 合で付着しているグリコーゲン代謝に関係する酵素の両方があ ることも示唆している。後に、Fischer とStetten (22) は骨格筋 から単離されたグリコーゲン標品には〜40-50\%のタンパク質 が含まれることを報告した。彼らと、後にはCohen (23) は、そ れらのタンパク質はグリコーゲン代謝において重要な酵素が非 共有結合したものであるとしている。これらのタンパク質は、 glycogen phosphorylase、phosphorylase kinase、glycogen synthase、 synthase kinase 2、およびcAMP kinase を含んでおり、少量の他 の酵素や筋小胞体も存在した。グリコーゲンに非共有結合した タンパク質、主にグリコーゲン会合酵素の存在は、肝臓や骨格 筋や他の臓器から高度に精製されたグリコーゲン標品に少量の タンパク質が存在することの説明として受け入れられてきた。 
amounts of protein present in highly purified glycogen preparations from liver, skeletal muscle and other organs.

However, data began to accumulate that the synthesis of an $\alpha-1-4$ glucan attached to a protein was present in liver (24, 25), heart (26), and retina (27) of mammals, Escherichia coli $(28,29)$ Neurospora crassa $(30)$, potato tubers $(31)$ and carrots (32). UDP-glucose at a micromolar concentration functioned as the glycosyl donor. The product formed was generally but not exclusively $(33,34)$ found in the TCA precipitable fractions of cell extracts (33-35). Data were obtained in potato tubers indicating that the product produced was a linear chain of glucose molecules in $\alpha-1,4$ linkage attached to a protein (33). The nature of the protein or the protein-glucan bond was not known. It was shown not to be a serine or threonine- $O$-glycosyl bond.

It also was speculated that the protein was a foundation or primer upon which new glycogen or starch molecules could be formed $(25,33)$. That is, it became incorporated into the glycogen or starch molecule. Also, in potato tubers enzymes were present which could cleave it from the ethanol precipitable product (starch).

Earlier investigators also had suggested that formation of a glucoproteic intermediate was a general mechanism for the synthesis of $\alpha$ - and $\beta$-glucans(36). Thus, the general concept was developed that a UDP-glucose-protein transglucosylase was present in plants and animals which produced a product (either a single glucose or most likely a linear array of glucose molecules attached to a protein) which then was acted upon by other enzymes to produce a mature starch or glycogen molecule.

Subsequently, the protein in potato tubers and carrots (32) and mammals to which glucosyl units were being attached was shown to be a $37-40 \mathrm{kDa}$ protein $(37,38)$. In carrots it was shown to be self-glycosylating (32). This protein has been purified from rabbit skeletal muscle, the amino acid sequence determined, and a specific tyrosine to which the glucose molecules are attached identified (39). The gene also has been cloned and sequenced (40). It is a manganese dependent selfglycosylating enzymic protein which may add up to 8-12 glucosyl units to itself in a linear array (41). This includes the addition of the first glucose to a specific tyrosine in the protein. Thus, it is a very unique enzyme. Not only is it a selfglucosylating enzyme, it gets incorporated in to the glycogen molecule. It has been given the name, glycogenin (42).

Subsequently, we (unpublished data) and others have obtained data indicating that not only does it glycosylate itself, it also will glycosylate malto-oligosaccharides and artificial alkylglucosides or maltosides (43-45). Indeed, dodecyl- $\beta$-Dmaltoside is reported to be an excellent substrate for the kidney enzyme (44). The rate of reaction is even faster than for self glycosylation. These observations then raise the possibility that not only does glycogenin self glycosylate and become in-
しかしながら、ほ乳類の肝臓 $(24 、 25)$ や心臓 (26) や網膜 (27)、また Escherichia coli (28、29)、Neurospora crassa (30)、バ レイショ塊茎 (31) そしてニンジンで、タンパク質に結合した $\alpha-1,4-$ グルカンの合成が起こるというデータが蓄積されはじめ た。 $\mu$ モル濃度レベルのUDP-グルコースがグリコシル供与体 として働き、生産物はすべてではないが $(33 、 34)$ 一般的に細胞 抽出物のTCA沈殿画分として検出される。バレイショ塊茎にお いて得られたデータでは、生産物はタンパク質に結合した直鎖 状の $\alpha-1,4-$ グルカンであることが示された (33)。そのタンパク 質の性質、あるいは夕ンパク質とグルカンの結合の性質につい ては分かっていない。セリンあるいはトレオニン-O-グリコシル 結合でないことは示されている。

そのタンパク質が新たなグリコーゲンやデンプン分子が合 成されるための基盤、あるいはプライマーであるという推論も なされた (25、33)。すなわち、それがグリコーゲンやデンプン 分子に取り込まれるということである。また、バレイショ塊茎 においてはそのタンパクをエタノール沈殿画分(デンプン)から 切り放しうる醳素が存在した。

初期の研究者たちは、糖タンパク中間体の形成が $\alpha-$ グルカ ンと $\beta$-グルカン合成における一般的機構であるとも考えた (36)。このように、UDP-グルコースータンパク質 transglucosylase が植物および動物中に存在して、ある生産物 (単一のグルコー ス、あるいはもっと可能性が高いところではグルコースの直鎖 がタンパク質に結合したもの) を合成し、それが他の酵素の作 用を受けて成熟デンプンやグリコーゲン分子ができるという一 般概念が発展してきた。

その後、バレイショ塊茎、ニンジン (32)、および動物にお いてグルコシル残基が付加されるのは37-40kDaのタンパク質で

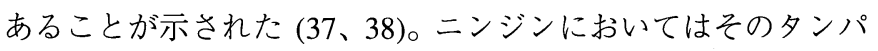
ク質は自己グリコシル化を行うことが報告された (32)。この夕 ンパク質はウサギ骨格筋から精製されて、そのアミノ酸配列が 決定され、またグルコース分子が付加される残基として特異的 なチロシン残基が同定された (39)。遺伝子のクローン化と塩基 配列決定も行われた (40)。そのタンパク質はマンガン依存性の 自己グリコシル化酵素であり、自分自身に8〜12残基までのグ ルコースを直鎖状に付加する (41)。この過程は特異的チロシン 残基への最初のグルコース基の付加を含んでいる。非常にユ ニークな酵素であり、自己グルコシル化酵素であるというだけ でなく、グリコーゲン分子に取り込まれる。この酵素は glycogenin と名付けられた (42)。

その後、私たち (未発表デー夕)、㧧よび他の研究者らはそ れが自己をグリコシル化するだけでなく、マルトオリゴ糖、あ るいは人工のアルキルグルコシドやマルトシドをもグリコシル 化することを示すデー夕を得た (43-45)。実際、ドデシル - $\beta-D-$ マルトシドは腎臓の酵素にとって非常によい基質であることが 報告されている (44)。その反応速度は自己グリコシル化よりも 早い。これらの観察から次のような可能性が考えられた。すな わち、glycogeninが自己をグリコシル化して成長するグリコー ゲン分子に基盤あるいはプライマーとして取り込まれるだけで 
corporated into the growing glycogen molecule as the backbone or primer, it also may catalyze the glycosylation of endogenous maltosaccharides or other endogenous substrates such as alkyl derivatives of maltose or malto-oligosaccharides, which in turn may function as primers. That is, glycogenin may have a dual function.

\section{Malto-Oligosaccharides}

The presence of malto-oligosaccharides in tissue has been reported by several investigators. Beloff-Chain et al. (46) identified a series of malto-oligosaccharides in diaphragm muscle the largest of which was at least malto-heptaose ( 7 glycosyl units in length). The production of these was accelerated by addition of insulin to an incubated diaphragm preparation. Fishman and Sie (10) reported the isolation of the same family of oligosaccharides up to malto- decaose ( 10 glycosyl units in length) and even higher from rat liver. They speculated that they were derived from the endogenous degradation of glycogen. However, in a subsequent publication using ${ }^{14} \mathrm{C}$ labeling experiments (47), they concluded that it was likely that the oligo-saccharides were precursor substrates for glycogen synthesis. Mordoh et al. (3) homogenized rat liver in $\mathrm{HgCl}_{2}$ in order to inhibit enzymic activity and reported the presence of oligosaccharides but the concentration $(1.3 \mu \mathrm{mol} / \mathrm{g}$ liver using maltose as a standard) was lower. The concentration also did not change with oral sucrose administration. This was in contrast to the increase with feeding reported by Sie and Fishman (47). The higher concentration reported by Sie and Fishman they attributed to endogenous- $\alpha$-amylase not being inhibited during preparation of the liver for assay. They did not consider the amount present to be significant.

Giri et al. (48) described an enzyme preparation from rat liver and brain which generated from maltose a series of $\alpha-1,4$ oligo-saccharides, liberating glucose in the process. A similar glucosylating activity was reported in rabbit liver (49) but these activities have never been confirmed. A D- or disproportionating enzyme has been described in potatoes. This enzyme transferred maltosyl or higher malto-oligosaccharyl residues from oligo- and polysaccharides to various receptors. The glucose concentration in the incubation mixture appeared to regulate the average chain lengths of the maltodextrin produced (50).

The importance, if any, of these transglucosylase activities or of $\alpha$-amylase or $\alpha$-glucosidase activities in glycogen metabolism remains unknown. However, they could provide a non-protein bound primer for synthesis of a glycogen molecule by glycogen synthase and branching enzyme. It should be noted that glycogen synthase may use oligosaccharides as short as maltotetraose as a substrate but the rate was very slow (19).

Thus, that oligosaccharides or small branched or unbranched maltodextrins either produced by cleavage of these
なく、内在性のマルトオリゴ糖、あるいはマルトースやマルト オリゴ糖のアルキル誘導体のような他の内在性基質のグリコシ ル化を触媒し、それがプライマーとして機能するという可能性 である。すなわち、glycogenin は2つの機能を持つのかもしれな い。

D. マルトオリゴ糖

組織中のマルトオリゴ糖の存在は数人の研究者によって報 告されている。Beloff-Chain ら (46) は横隔膜筋肉中に存在する 一連のマルトオリゴ糖を同定したが、そのうちの最大のものは 少なくともマルトヘプタオース (7 グルコース残基長) 以上で あった。これらの生産は培養横隔膜にインシュリンを添加する ことによって促進された。Fishman と Sie (10) はラット肝臓から マルトデカオース (10 グルコース残基長) までの、そしてより 長鎖の同種オリゴ糖の単離について報告している。彼らは、そ れらのオリゴ糖が内在性のグリコーゲンの分解によって生じた と推測している。しかしながら、年Cラベル実験を用いたその後 の報告では (47)、そのオリゴ糖はグリコーゲン合成の前駆体で あるらしいと結論している。Mordohら (3) は、酵素活性を阻害 するためにラット肝臓を $\mathrm{HgCl}_{2}$ 存在下でホモゲナイズし、濃度 はもっと低いが (マルトースを標準として $1.3 \mu \mathrm{mol} / \mathrm{g}$ liver)、マ ルトオリゴ糖が存在することを報告した。その濃度はしょ糖の 経口投与によっても変化しなかった。このことは、Sie と Fishman (47)により報告された、給慨による増加とは相反して いた。Sieと Fishmanによってより高い濃度が観察された原因と して、彼らは測定のための肝臟調製中に内在性 $\alpha$-amylaseが阻害 されていなかったことを指摘しており、その存在量は有意では ないと考えている。

Giriら (48) は、グルコースを遊離しながらマルトースから 一連の $\alpha-1,4$-オリゴ糖を生成する酵素標品をラットの肝臓と脳 から得ている。同様なグルコシル化活性がウサギ肝臟において 報告されているが、これらの活性はまだ確認されていない。バ レイショには、D-醰素、すなわち不均化酵素が存在することが 示されている。この酵素はマルトシル基、あるいはより長いマ ルトオリゴシル基をオリゴ糖や多糖から種々の受容体に転移す る。反応液中におけるグルコース濃度が生産されるマルトデキ ストリンの平均鎖長を制御しているらしい (50)。

これらの transglucosylase 活性、 $\alpha$-amylase 活性、あるいは $\alpha$-glucosidase活性のグリコーゲン代謝において重要であるかど うかは不明である。しかし、それらの酵素は glycogen synthase と branching enzymeによるグリコーゲン分子合成に対して、タン パク質非結合型プライマーを供給しうる。Glycogen synthaseが、 速度は非常に遅いが、マルトテトラオースのような短いオリゴ 糖も基質として使用しうることは注目すべきである (19)。

このように、glycogenin 初期生産物やタンパク質非結合型 グリコーゲン分子の部分分解によって生じる、オリゴ糖、低分 
from a glycogenin initiated product or from partial degradation of protein-free glycogen molecules are substrates for a formation of new glycogen molecules is a distinct possibility.

\section{E. $\alpha$-Glucosidases in Liver}

A lysosomal, acid, $\alpha$-glucosidase is present which hydrolyzes both $\alpha-1,4$ and $\alpha-1,6$ glycosyl bonds and thus can completely hydrolyze glycogen to glucose or maltose. In its absence glycogen of normal structure accumulates in lysosomes resulting in death or disability (glycogen storage disease, Type II or Pompe's disease) (51). Thus, autophagy of glycogen has been considered to be important in glycogen degradation. The mechanism by which glycogen molecules are selected for and taken up by lysosomes remains unknown, as does its possible regulation. Also, whether the glycogen taken up by the lysosomes is derivatized by glycogenin is not known, nor are the actual products released from microsomes in vivo.

An additional $\alpha$-glucosidase active at neutral $\mathrm{pH}$ has been described which releases glucose from glycogen. It is referred to as $\alpha$-glucosidase C. It has been purified, and the gene cloned, sequenced, and assigned to chromosome $15(52,53)$. However, its role, if any, in glycogen metabolism is unknown. In this regard, some investigators have attributed the inability to identify large proteoglycogen species in skeletal muscle extracts, after labeling with ${ }^{14} \mathrm{C}$ using ${ }^{14} \mathrm{C}$-UDP-glucose as substrate, to the presence of an $\alpha$-glucosidase (54).

Whether there is a cytosolic $\alpha$-amylase active at a neutral $\mathrm{pH}$ in addition to the lysosomal acid $\alpha$-amylase remains uncertain but has not been identified in liver.

\section{F. Proteoglycogen and Glycogen Metabolism}

In animal skeletal muscle, glycogen preparations have invariably contained protein with amounts up to $3 \%$ by weight $(8,55)$. The minimal amount present generally is $\sim 0.3-$ $0.4 \%$ (54). Based on the latter, it has been calculated that there is at least one glycogenin molecule present for each glycogen molecule $(61,62)$. Also, it has been reported that free reducing groups are not present in skeletal muscle glycogen (54). This has led to the concept that in skeletal muscle, all of the glycogen molecules have attached to them a glycogenin molecule. That is, they are all proteoglycans even though the glycan may be extremely large relative to the size of the protein.

However, highly purified preparations of liver glycogen obtained under conditions which minimize degradation have yielded preparations in which the protein content varied between 0.04 to less than $0.01 \%$ or was unmeasurable $(2,3,54)$. In liver, if one assumes a molecular weight of $8,000 \mathrm{kDa}$ for the fundamental, mature, glycogen particle, then the molar ratio of glycogenin to glycogen would be 1:12 at a protein content of $0.04 \%$ by weight for ethanol precipitable glycogen. That is, only 1 glycogenin protein for each 12 glycogen molecules. The
子の分岐、あるいは非分岐マルトデキストリンが新たなグリ コーゲン分子合成の基質になるという別の可能性がある。

\section{E. 肝臓における $\alpha$-glucosidases}

$\alpha-1,4-$ と $\alpha-1,6-$ グルコシド結合の両方を加水分解し、グリ コーゲンを完全にグルコースやマルトースに加水分解しうるリ ソソーム酸性 $\alpha$-glucosidase が存在する。それが存在しないと、 正常な構造のグリコーゲンがリソソームに蓄積し、死に至るか、 障害を生じる (2 型糖原病、あるいはポーンプ病) (51)。このよ うに、グリコーゲンの自家融解はグリコーゲン分解において重 要であると考えられている。グリコーゲン分子がリソソームに よって選択され、取り込まれる機構はわかっておらず、その可 能な制御も不明である。また、リソソームに取り込まれるグリ コーゲンが glycogenin の誘導体であるかどうかも不明であり、 in vivoにおいて顆粒体から放出される実際の生産物もわかって いない。

グリコーゲンからグルコースを遊離する、中性 $\mathrm{pH}$ 域で活 性のある別の $\alpha$-glucosidase が報告されており、 $\alpha$-glucosidase C と呼ばれている。この酵素は精製されており、その遺伝子のク ローン化と塩基配列決定が行われ、また15番染色体に存在する

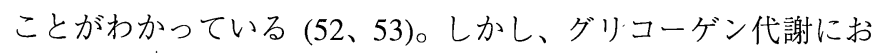
ける機能は、もしあるとしても分かっていない。この点に関し

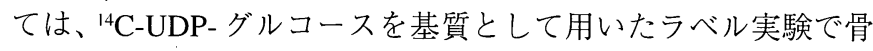
格筋抽出液から高分子プロテオグリコーゲンが同定されない原 因として、ある研究者たちは $\alpha$-glucosidase の存在をあげている (54)。

リソソームに存在する酸性 $\alpha$-amylaseの他に中性 $\mathrm{pH}$ 域で活 性のある細胞質 $\alpha$-amylase が存在するかどうかは不明であり、 肝臟では同定されていない。

\section{F. プロテオグリコーゲンとグリコーゲンの代謝}

動物の骨格筋においては、グリコーゲン標品は重量にして $3 \%$ までのタンパク質を必ず含んでいる $(8 、 55)$ 。最少量は一般 に〜0.3-0.4\%である (54)。後者の值に基づくと、それぞれのグ リコーゲン分子には少なくとも 1 個の glycogenin 分子が存在す る計算になる。さらに、骨格筋グリコーゲンには遊離の還元末

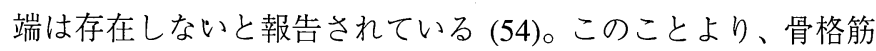
においてはすべてのグリコーゲン分子が glycogenin と結合して いると考えられる。すなわち、タンパクの大きさに比べて糖部 分が極端に大きいが、それらグリコーゲンはすべてプロテオグ リカンである。

しかし、分解を最小限にするような条件で、高度に精製さ れた肝臓グリコーゲン標品においては、タンパク質含量は $0.04 \%$ から $0.01 \%$ 以下、あるいは検出限界以下であった (2、3、 54)。肝臟において、基本的な成熟グリコーゲン粒子の分子量を $8,000 \mathrm{kDa}$ と仮定すると、glycogenin とグリコーゲンのモル比は $1: 12$ になる。これは、 $0.04 \%$ タンパク質を含むエタノール沈殿 性グリコーゲンの場合である。つまり、12個のグリコーゲン分 子に対して glycogenin タンパク質はわずかに1個である。一般 
ratio is likely to be greater if even smaller amounts of protein are present as has generally been reported. This is less than the proposed presence of one glycogenin for each alpha particle (63).

Many years ago the presence of reducing groups in rabbit liver glycogen samples with molecular weights of 0.1 to 34 million (6) was reported. The glycogen samples were subjected to anaerobic strong alkali treatment. The latter results in production of isosaccharinic acid at the reducing end of the molecule. Skeletal muscle or other tissues were not studied. In these studies care was not taken to rapidly remove and process the liver samples and all samples were subjected to acid or alkali extraction. Thus, they likely had been modified.

Overall, the best evidence obtained many years ago is that the majority of glycogen molecules in liver in contrast to skeletal muscle (and probably other tissues), do not have a glycogenin protein attached. Whether the majority have a free reducing end present has been less certain.

We have obtained preliminary data which indicate that indeed free reducing ends are present (Table I), and that glycogen molecules with free reducing ends may represent the majority of molecules present.

If a large number of free reducing groups are present and
に報告されているようにタンパク質の量がさらに低いとすれば、 この比はもっと大きくなるだろう。この比は、それぞれのアル ファ粒子当り 1 分子の glycogenin が存在するという提案から与 えられる比よりも小さいのである。

ずっと以前に、分子量 10 万から 3,400 万のウサギ肝臟グリ コーゲンに還元性末端が存在することが報告された(6)。そのグ リコーゲンサンプルは酸素非存在下で強アルカリ処理された。 その処理は、分子の還元性末端でのイソサッカリン酸の生成を もたらすのである。骨格筋、あるいは他の臟器では研究されて いない。これらの研究では肝臓サンプルをすばやく取り出して 処理するのに注意が払われておらず、すべてのサンプルは酸あ るいはアルカリで抽出されている。したがって、サンプルは修 飾されていた可能性がある。

全体として、肝臓のグリコーゲン分子の大部分は、骨格筋 の(そしておそらくは他の臟器の) グリコーゲンと違って glycogenin タンパクを持たないと言うことを示す良い証拠が多 年にわたって得られている。大部分が遊離の還元末端を持って いるかどうかは不明確であった。

私たちは実際に遊離の還元末端が存在し (表 I)、その還元 末端を持つグリコーゲン分子が大部分を占めることを示す予備 的なデー夕を得ている。

もし、多数の遊離還元末端が存在し、かつglycogeninがす

Table I. Stoichiometry of Incorporation of Tritium into Glycogen. Glycogen pellets $(200,00 \times g)$ were prepared from fed rat livers using the least manipulation possible, and compared with a commercial rabbit liver glycogen preparation. They were incubated for 2 hours with an excess of ${ }^{3} \mathrm{H} \mathrm{NaBH}_{4}$. Replicate experiments were performed on different days. The number of moles of aldehyde reduced in a population of glycogen molecules was calculated based on a molecular weight of glycogen of $8000 \mathrm{kDaltons}$, and the appropriate $\mathrm{cpm} / \mathrm{pmole}$ of ${ }^{3} \mathrm{H} \mathrm{NaBH}_{4}$.

\begin{tabular}{lccc}
\hline & cpm & pmoles ${ }^{3}$ H incorporated & $\begin{array}{c}\text { \% molecules } \\
\text { reduced }\end{array}$ \\
\hline \multirow{2}{*}{ Commercial Rabbit Liver Glycogen } & 2136 & 15.38 & $246 \%$ \\
& 2820 & 9.92 & $158 \%$ \\
& 2260 & 7.96 & $128 \%$ \\
& & & \\
Rat Liver Glycogen Pellet Prep \#1 & 3550 & 12.5 & $94 \%$ \\
& 2558 & 28.2 & $134 \%$ \\
& 2408 & 17.4 & $130 \%$ \\
Rat Liver Glycogen Pellet Prep \#2 & 3194 & & $128 \%$ \\
& 6632 & 23.0 & $266 \%$ \\
& 5340 & 47.8 & $213 \%$ \\
\hline
\end{tabular}

These preliminary data indicate that free reducing groups are present in glycogen. Since greater than $100 \%$ incorporation of tritium was observed in several samples, it indicates that the average molecular weight of the glycogen particles present must be less than $8000 \mathrm{kDa}$. This is to be expected since the molecular weight of glycogen is known to be polydisperse. Protein was undetectable in the pellet preparations. 
if glycogenin is assumed to initiate the formation of all new glycogen molecules, then a mechanism for cleaving glycogenin from the glycogen molecules must be present. This could be an enzymic process and could be important in regulating the rate of formation of new individual glycogen molecules. That is, it could regulate the number of glycogen molecules present in different physiological states. Alternatively, malto-oligosaccharides may be produced and function as primers for new glycogen synthesis. These are possibilities that we currently are pursuing.

\section{G. Is Proteoglycogen a Unique Species?}

Using bovine retinal membrane preparations Lacoste $e t$ al. (56)have provided evidence that a small proteoglycogen containing glycogenin is found primarily in the microsomal fraction on ultracentrifugation and is attached to a membranous structure. This proteoglycan is TCA precipitable. Incubation with a micromolar concentration of UDP-glucose resulted in labeling of the proteoglycogen. Incubation with a higher concentration of UDP- ${ }^{14} \mathrm{C}$ glucose resulted in release from the membrane structure and the product now became soluble in TCA and precipitable by ethanol. This suggested expansion of the glycan to a large polysaccharide structure. A pulse-chase experiment indicated the conversion of the proteoglycan, in which the glycogen moiety was small, to one in which it was considerably larger. The expansion of the glycogen structure was attributed to the activity of glycogen synthase and branching enzyme, although the actual structure of the product was not determined. Addition of a detergent (SDS) also resulted in dissociation from the membranes. In this regard it has been reported that the glycogen in liver of fasted rats is difficult to solubilize and that the glycogen in a $12,000 \times g$ pellet was only completely extracted when chloroform was added (57). Thus, these data suggest that a fraction of nascent glycogen may be membrane bound.

Interestingly, in the retinal membrane preparations (56), addition of rabbit liver glycogen in excess during the incubation with $10 \mathrm{mM}$ UDP-glucose did not result in a competitive inhibition of the expansion of the proteoglycogen species. This suggests the presence of a mechanism for addition of glucosyl units to a proteoglycogen which is independent from that of "free" glycogen. Whether glycogen synthase and branching enzyme are responsible for expansion of both forms remains to be determined. We also have provided data suggesting that the two processes are regulated independently in vivo (58).

In liver extracts from 24 hour fasted rats, essentially all glycogenin was present in a free form, i.e. it was not incorporated into a glycogen molecule (58). Glucose could be transferred from UDP-glucose to the glycogenin. Following oral glucose administration to fasted rats, the glycogen concentration increased for one hour before glycogenin was incorporated
ベての新しいグリコーゲン分子の合成を開始するのであるとす ると、グリコーゲンから glycogenin を切断する機構が存在する はずである。この機構は酵素によるプロセスであることが考え られ、また新しい別のグリコーゲン分子の合成速度を制御する のに重要であるかもしれない。つまり、異なる生理的状態にお いてグリコーゲン分子の数を制御するかもしれない。これとは 別に、マルトオリゴ糖が生産されて新たなグリコーゲン合成の プライマーとして働くことも考えられる。これらが、現在私た ちの追求している可能性である。

\section{G. プロテオグリコーゲンが唯一の分子種か？}

牛網膜膜標品を用いて Lacoste ら (56) は、glycogenin を含 む低分子プロテオグリコーゲンが超遠心による顆粒体画分に主 に見いだされ、それが膜構造に結合していることを示す証拠を 得ている。このプロテオグリコーゲンはTCAで沈殿する。 ル濃度のUDP-グルコースとともにインキュベートすると、そ のプロテオグリコーゲンはラベルされた。より高濃度の ${ }^{14} \mathrm{C}-$ UDP-グルコースとインキュベートすると、膜構造から遊離し、 その生産物はTCA に溶解しエ夕ノールで沈殿するようになっ た。このことはグリカンが高分子多糖構造体に伸長したことを 示唆する。パルス-チェース実験によって、このプロテオグリカ ンの小さかったグリコーゲン部分が顕著に大きくなったことが 示された。そのグリコーゲン構造の伸長は glycogen synthase 活 性と branching enzyme 活性によるとされたが、実際の生産物構 造は決定されていない。界面活性剂 (SDS) の添加によっても、 膜からの解離が起こった。一方、絶食させたラットの肝臓グリ コーゲンは溶解させることが難しく、12,000 × $g$ で沈殿させた グリコーゲンはクロロホルムを添加したときにのみ完全に抽出 されることが報告されている。したがって、これらのデー夕は 新生グリコーゲン画分が膜に結合しているかもしれないことを 示唆している。

興味深いことに、網膜膜標品 (56) において、10mM UDPグルコースとのインキュベーション中に過剩量のウサギ肝臓グ リコーゲンを添加しても、プロテオグリコーゲンの伸長の拮抗 阻害は起こらない。このことはプロテオグリコーゲンへのグル コシル残基の付加機構が存在し、それは“遊離”グリコーゲンへ の付加機構とは別であることを示唆している。Glycogen synthase と branching enzymeが両形態の伸長を担っているのかど うかは分かっていない。私たちはこれらの2つの過程が in vivo で独立に制御されていることを示唆するデー夕も報告している (58)。

24時間絶食させたラットの肝臓抽出液中においては、実質 上すべての glycogenin が遊離状態で存在する。すなわち、グリ コーゲン分子に取り込まれていない (58)。グルコースはUDPグルコースから glycogeninに転移されうる。絶食ラットへのグ ルコース経口投与の後、グリコーゲン濃度は 1 時間で上昇した 
into a large proteoglycan product. Thus, there appears to be a "free" glycogen synthetic pathway, and a proteoglycogen synthetic pathway which are regulated independently in liver as well as in retinal membrane preparation.

In the TCA precipitable fractions of the retinal membranes, the glycogen to which glycogenin was attached had an average $M_{r}$ of $470 \mathrm{kDa}$ as determined on a sizing column. The TCA soluble fraction had an $\mathrm{M}_{\mathrm{r}}$ of $\sim 700 \mathrm{kDa}$, i.e., both were considerably smaller than a mature glycogen molecule (35). Lomako and associates (59)subsequently reported that in skeletal muscle preparations the TCA precipitable form of glycogen also had an $\mathrm{M}_{\mathrm{r}}$ of approximately $400 \mathrm{kDa}$, i.e., considerably smaller than the $\mathrm{M}_{\mathrm{r}}$ of the TCA soluble glycogen ( 8000$10,000 \mathrm{kDa})$. They have referred to the former as "proglycogen". They also have commented that species smaller than $400 \mathrm{kDa}$ are uncommonly reported. This suggested to the authors that a glycogenin initiated nascent glycogen molecule is rapidly expanded to this $400 \mathrm{kDa}$ species. Using primary cultures of astrocytes from 1-2 day old rats they also provided evidence for an independent regulation of the TCA insoluble and soluble fractions and for the TCA precipitable species being a precursor of the TCA soluble species (60). Thus, in retina, skeletal muscle, astrocytes and liver(58)there is evidence for different forms of glycogen being present and for independent regulation of each. In skeletal muscle, glycosylation of the $400 \mathrm{kDa}$ species and those with a $\mathrm{M}_{\mathrm{r}}$ between 42 and $400 \mathrm{kDa}$ occurred with a micromolar concentration of ${ }^{14} \mathrm{C}$-UDP-glucose(59)a concentration considerably below the $K_{\mathrm{m}}$ for UDP-glucose of glycogen synthase. Whelan and associates $(60,62)$ suggest a specific proglycogen synthase in addition to classical glycogen synthase is present and this accounts for the activity observed or that glycogen synthase having different phosphorylation states has affinities that are different for "proglycogen" and glycogen. To our knowledge, conversion of proteoglycogen species to a mature $(8,000 \mathrm{kDa})$ species has not been reported in vitro.

In liver little is known about the distribution of glycogen between TCA precipitable and soluble fractions, the size of the proteoglycogen in these fractions or how they may vary with feeding or fasting or with glucose administration, etc.

\section{H. Summary}

In summary, evidence is developing that indicates the presence of two or more forms of proteoglycogen. In liver a protein-free species appears to be present as well. The interrelationships among these species, their regulation, and their role in fuel metabolism remains to be determined.

Current data also indicate that the initiation of glycogen molecules is a much more complex process than originally believed. It now is clear that a self-glycosylating protein containing a glucose molecule attached by its reducing end to a tyrosyl
が、これは glycogenin が高分子プロテオグリカンに取り込まれ る前であった。したがって、肝臓や網膜膜標品中には“遊離”グ リコーゲンの合成経路が存在し、プロテオグリコーゲン合成経 路は別に制御さているらしい。

網膜膜のTCA沈殿画分における glycogenin結合型グリコー ゲンの平均分子量はカラムで決定したところ $470 \mathrm{kDa}$ であった。 TCA 可溶画分の分子量は〜 700kDaであり、双方とも成熟グリ コーゲン分子よりも明らかに小さかった (35)。Lomako と共同 研究者たち (59) が、後に報告しているところでは、骨格筋標品 中の TCA 沈殿型グリコーゲンの分子量も約 $400 \mathrm{kDa}$ であり、 TCA 可溶型グリコーゲン ( 8000-10,000kDa) よりも明らかに 小さかった。彼らは前者を“プログリコーゲン”と呼んでいる。 彼らはまた、400kDaよりも小さい分子種はほとんど報告されて いないと述べている。このことから彼らは、glycogeninが合成開 始した新生グリコーゲンは速やかにこの400kDa産物に伸長され ることを示唆している。さらに、1-2日齢のラットの一次培養神 経膠星状細胞を用いて、TCA不溶画分と可溶画分の制御が独立 に行われていることと、TCA沈殿分子がTCA 可溶分子の前駆体 であることを示す証拠も報告している $(60)$ 。のように、網膜、 筋肉、神経細胞、および肝臓 (58) において、グリコーゲンの異 なる形態が存在し、それぞれ別個に制御されていることを示す 証拠が得られている。骨格筋において、400kDa産物のグリコシ ル化と 42 から $400 \mathrm{kDa}$ の産物のグリコシル化は $\mu$ モル濃度の

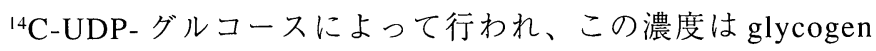
synthase の UDP-グルコースに対する Kmよりもかなり低い。 Whelan ら (60、62) は2つの可能性を示している。つまり、特異 的な proglycogen synthase が古典的 glycogen synthase とは別に存 在し、観察された活性の原因である可能性、あるいはglycogen synthase の異なるリン酸化状態が存在し、それぞれの親和性が “プログリコーゲン”とグリコーゲンに対して異なるという可能 性である。私たちの知る限りでは、プロテオグリコーゲンの成 熟 $(8,000 \mathrm{kDa})$ 産物への in vitroでの変換は報告されていない。

肝臓においては TCA 沈殿画分と可溶画分の間のグリコー ゲンの分布や、これらの画分のプロテオグリコーゲンの大きさ、 それらが給飭や絶食やグルコース投与によってどう変化するか、 などについてはほとんど分かっていない。

H. まとめ

まとめると、二つあるいはそれ以上の種類のプロテオグリ コーゲン形態が存在することを示寸証拠が蓄積されつつある。 肝臟においてはタンパクを結合しない分子種も存在する。これ らの分子種の相互関係、制御、エネルギー代謝における役割に ついては不明である。

現在のデータが示すところでは、グリコーゲン分子の合成 開始反応は信じられていたよりもずっと複雑である。自己グリ コシル化タンパク質、そのチロシン残基にグルコース分子が還 元末端で結合しているのであるが、このタンパクがグリコーゲ 
(a)

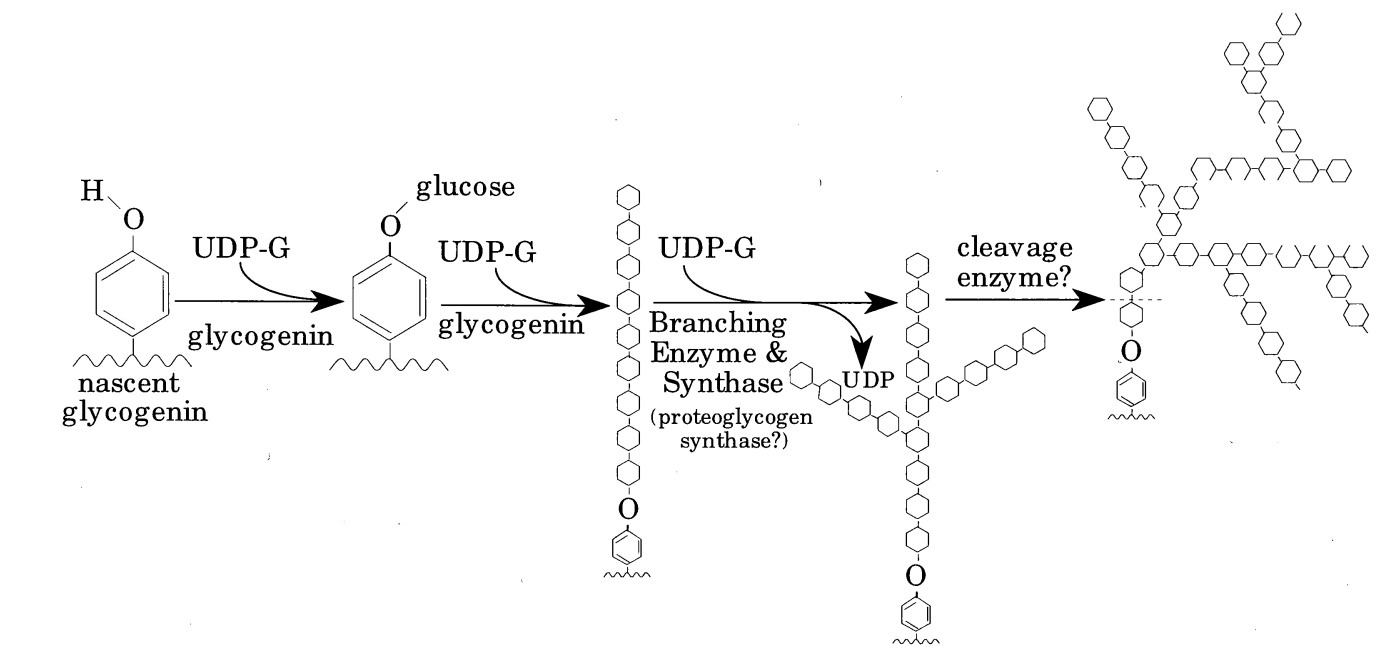

(b)

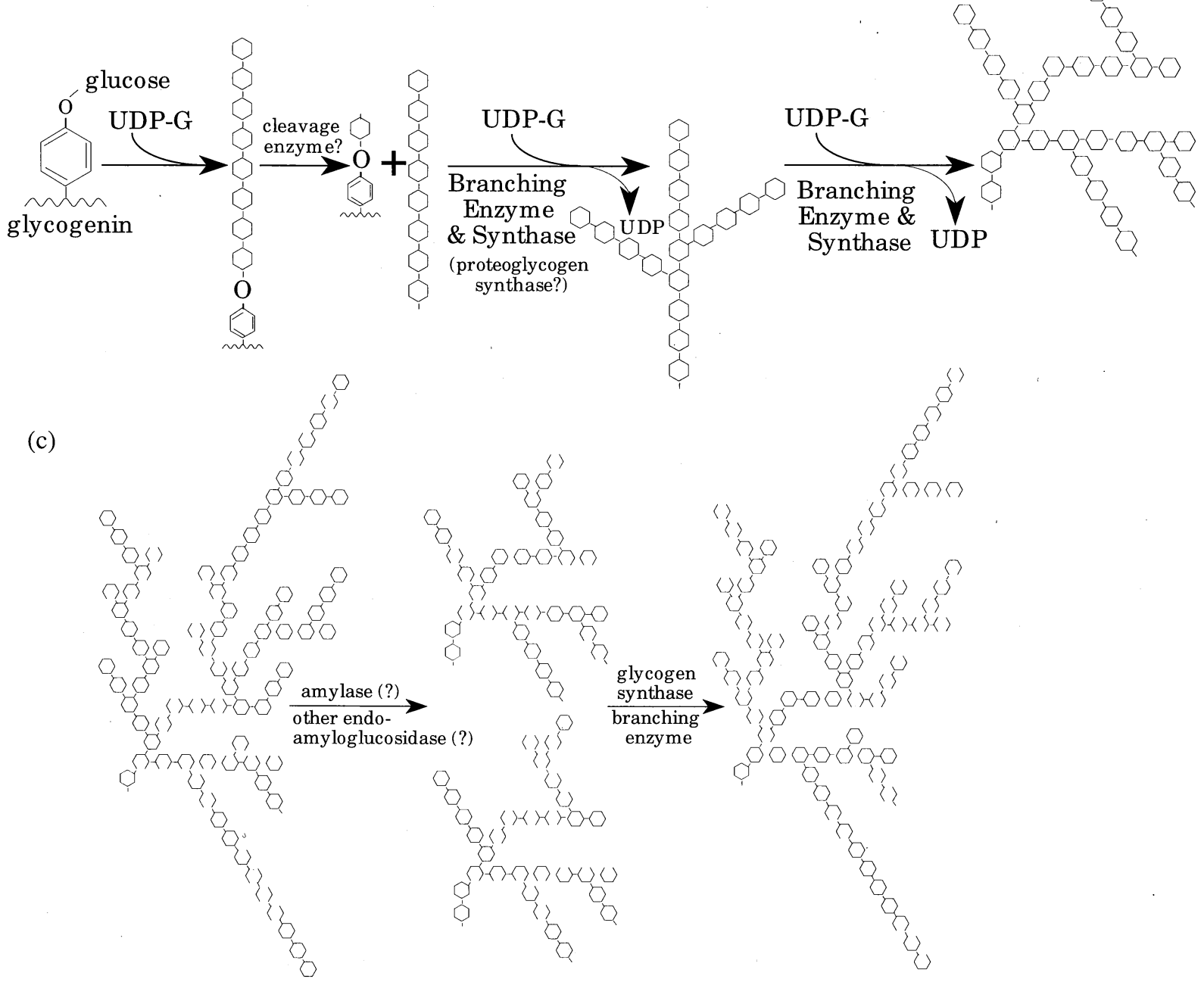

$00000-0,00000$

Fig. 1. Potential pathways for glycogen synthesis. (a) Glycogenin attaches several glucosyl units to itself. After reaching a length of $8-12$ units, glycogen synthase adds additional glucosyl units and in association with branching enzyme produces a highly branched structure. At some time after a branched structure has been formed, an enzyme catalyzes a hydrolytic cleavage from glycogenin. The products are a branched polysaccharide and glycogenin. The latter now can be used to initiate synthesis of a new polysaccharide. (b) Before branching occurs, while the nascent glycogen molecule is merely a linear chain, an enzyme catalyzes a hydrolytic cleavage from glycogenin. The products are glycogenin and an oligosaccharide. The oligosaccharide then may be a substrate for glycogen synthase and branching enzyme. (c) In this scenario, a glycogen molecule, either independent of, or still attached to the glycogenin protein, is hydrolyzed into smaller branched or linear structures by amylase and/or another endo-amyloglucosidase. These structures then become substrates for glycogen synthase and branching enzyme which expand them into a mature glycogen molecule. 
residue in the protein may initiate the synthesis of a glycogen molecule and that the protein may become permanently attached to it. This enzyme which glycosylates itself has been best studied in skeletal muscle. However, even in this organ regulation of the amount of enzyme or of its catalytic activity is poorly understood. Its role in the overall regulation of the amount of glycogen that may be stored in different physiological or pathological states also remains uncertain.

In liver the initiation of glycogen molecules is likely to be even more complex. A similar enzyme is present but whether it is identical to skeletal muscle glycogenin is not known but it is likely to be the case (40,62-64). In addition, in liver the majority of glycogen molecules apparently do not have attached to them a glycogenin molecule. How these glycogenin-free glycogen molecules are generated is completely unknown. Whether they are derived from the hydrolysis of the bond between glycogenin and glycogen (Fig. la) or hydrolysis of a glycogenin (Fig. 1b) synthesized malto-oligosaccharide attached to glycogenin or are generated by fragmentation of glycogen itself by amylase or another enzyme producing either linear or branched products (Fig.1c) also is completely unknown. It also is possible that the glycogeninbound and glycogenin-free glycogen molecules are synthesized independently and are regulated independently and have a different cellular location. In any regard, how glycogenin-free glycogen molecules are generated is likely to play an important role in determining the number of glycogen molecules in a liver cell in different physiological and pathophysiological states. It also is likely to regulate the total amount of glycogen that can be stored, i.e. the cellular capacity to store glycogen.

\section{Acknowledgements}

Supported by Merit Review Research Funds from the Department of Veterans Affairs, and grant \#DK43018 from the National Institutes of Health. The authors would like to thank Claudia Durand for her expert secretarial assistance.
ン分子の合成を開始することと、そしてそのまま結合している ことは今や明らかである。この自己グリコシル化酵素は骨格筋 において最もよく研究されている。しかし、この組織において さえ酵素量や酵素活性の制御についてはほとんど理解されてい ない。異なる生理的状態や病的状態のときに貯蔵されるグリ コーゲン量の全体的な制御における役割も分かっていない。

肝臟においてはグリコーゲン分子の合成開始はさらに複雑 であるらしい。よく似た酵素が存在するが、それが骨格筋 glycogenin と同一であるかどうかは分からない。しかしその可

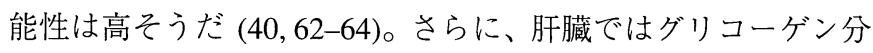
子の大部分が明らかにglycogeninを結合していない。これらの glycogenin 非結合型グリコーゲン分子がどのようにして生じる のか全く不明である。それらが glycogenin-グリコーゲン間結合 の加水分解 (図 1a) やマルトオリゴ糖を結合する glycogenin の 加水分解 (図 $1 \mathrm{~b}$ ) によって生じるのか、あるいはグリコーゲン 自体がアミラーゼや他の酵素によって直鎖の糖や分岐糖に分解 されて (図 1c) それから生じるのかも全く明らかにされていな い。Glycogenin 結合型および非結合型のグリコーゲン分子が別 個に合成されたり、別個に制御されていたり、別の場所に存在 しているという可能性も考えられる。いずれにしても、 glycogenin 非結合型グリコーゲン分子がどのように合成される かは、異なる生理的状態や病的状態における肝臓細胞中のグリ コーゲン分子数を決定する上で重要な要素になるであろう。貯 蔵されうるグリコーゲンの総量、つまり細胞のグリコーゲン貯 蔵容量も制御しているかもしれない。

\section{江崎グリコ株式会社・生物化学研究所}

\section{高田 洋樹 訳}

\author{
Reference \\ 1. Lomako, J., Lomako, W.M., and Whelan, W.J. (1990) FEBS Lett. 268, 8-12 \\ 2. Calder, P.C. (1991) Int. J. Biochem. 23, 1335-1352 \\ 3. Mordoh, J., Krisman, C.R., and LeLoir, L.F. (1966) Arch. Biochem. Biophys. 113, 265-272 \\ 4. Fletterick, R.J., and Madsen, N.B. (1980) Ann. Rev. Biochem. 49, 31-61 \\ 5. Stetten, D., Jr., and Stetten, M.R. (1960) Physiol. Rev. 40, 505-537 \\ 6. Stetten, M.R., and Katzen, H.M. (1961) J. Am. Chem. Soc. 83, 2912-2918 \\ 7. Lazarow, A. (1942) Anat. Rec. 84, 31-50 \\ 8. Orrell, S.A., and Bueding, E. (1964) J. Biol. Chem. 239, 4021-4026 \\ 9. Willstätter, R., and Rohdewald, M. (1934) Z. Physiol. Chem. 225, 103-124 \\ 10. Fishman, W.H., and Sie, H.-G. (1958) J. Am. Chem. Soc. 80, 121-123 \\ 11. Nuttall, F.Q., Gannon, M.C., Bai, G., and Lee, E.Y.C. (1994) Arch. Biochem. Biophys. 311, 443-449 \\ 12. Tan, A.W.H., and Nuttall, F.Q. (1985) J. Biol. Chem. 260, 4751-4757 \\ 13. Bai, G., Zhang, Z., Werner, R., Nuttall, F.Q., Tan, A.W.H., and Lee, E.Y.C. (1990) J. Biol. Chem. 265, 7843-7848 \\ 14. Kaslow, H. R., Lesikar, D.D., Antwi, D., and Tan, A.W.H. (1985) J. Biol. Chem. 260, 9953-9956 \\ 15. Nuttall, F.Q., Gilboe, D.P., Gannon, M.C., Niewoehner, C.B., and Tan, A.W.H. (1988) Am. J. Med. 85, 77-85 \\ 16. Nuttall, F.Q., and Gannon, M.C. (1993) J. Biol. Chem. 268, 13286-13290 \\ 17. Nuttall, F.Q., Gannon, M.C., Kubic, V.L., and Hoyt, K.J. (1994) Genomics 19, 404-405
}


18. Goldemberg, S.H. (1962) Biochim. Biophys. Acta 56, 357-359

19. Larner, J. (1976) Mol. Cell. Biochem. 12, 131-136

20. LeLoir, L.F. (1964) in Control of Glycogen Metabolism (Whelan, W. J., and Cameron, M. P., eds.) pp. 68-86, J. and A. Churchill Ltd., London

21. Roe, J.H., Bailey, J.M., Gray, R.R., and Robinson, J.N. (1961) J. Biol. Chem. 236, 1244-1246 :

22. Fischer, C. J., and Stetten, M. R. (1966) Biochim. Biophys. Acta 121, 102-109

23. Cohen, P. (1978) Curr.Top. Cell Regul. 14, 117-195

24. Berthillier, G., Azzar, G.J.C., and Got, R. (1975) Eur. J. Biochem. 51, 275-282

25. Krisman, C.R. (1972) Biochem. Biophys. Res .Commun. 46, 1206-1212

26. Bartley, W., and Dean, B. (1968) Anal. Biochem. 25, 99-108

27. Curtino, J.A., Maccioni, H.J., and Caputto, R. (1979) J. Neurochem. 33, 139-147

28. Barengo, R., Flaviá, M., and Krisman, C.R. (1975) FEBS Lett. 53, 274-278

29. Barengo, R., and Krisman, C.R. (1976) Acta Physiol. Lat. Am. 26, 289-296

30. Takahara, H., and Matsuda, K. (1977) J .Biochem. (Tokyo) 81, 1587-1594

31. Lavintman, N., Tandecarz, J., Carceller, M., Mendiara, S., and Cardini, C. E. (1974) Eur. J. Biochem. 50, 145-155

32. Quentmeier, H., Ingold, E., and Seitz, H. V. (1987) Planta 171, 483-488

33. Tandecarz, J.S., Lavintman, N., and Cardini, C.E. (1975) Biochim. Biophys. Acta 399, 345-355

34. Aon, M.A., and Curtino, J.A. (1984) Eur. J. Biochem. 140, 557-566

35. Miozzo, M.C., LaCoste, E.R., and Curtino, J.A. (1989) Biochem. J. 260, 287.-289

36. Fredrick, J.F. (1971) Physiol. Plantarum 25, 32-34

37. Moreno, S., and Tandecarz, J.S. (1982) FEBS Lett. 139, 313-316

38. Rodriguez, I.R., and Whelan, W.J. (1985) Biochem. Biophys. Res. Commun. 132, 829-836

39. Smythe, C., Caudwell, F. B., Ferguson, M., and Cohen, P. (1988) EMBO J. 7, 2681-2686

40. Viskupic, E., Cao, Y., Zhang, W., Cheng, C., DePaoli-Roach, A. A., and Roach, P. J. (1992) J. Biol. Chem. 267, 25759-25763

41. Lomako, J., Lomako, W. M., and Whelan, W.J. (1990) Biochem. Int. 21, 251-260

42. Kennedy, L.D., Kirkman, B. R., Lomako, J., Rodriguez, I. R., and Whelan, W.J. (1985) in Membranes and Muscle (Berman, M.C., Gevers, W., and Opie, L.H., eds.) pp. 65-84, Oxford Press, Oxford

43. Lomako, J., Lomako, W.M., and Whelan, W.J. (1990) FEBS Lett. 264, 13-16

44. Manzella, S. M., Rodén, L., and Meezan, E. (1995) Glycobiology 5, 263-271

45. Alonso, M.D., Lomako, J., Lomako, W.M., and Whelan, W. J. (1995) J. Biol. Chem. 270, 15315-15319

46. Beloff-Chain, A., Catanzaro, R., Chain, A.B., Masi, I., Pocchiari, F., and Rossi, C. (1955) Royal Soc. London Proc. 143, 481-503

47. Sie, H.-G., and Fishman, W.H. (1958) Nature 182, 240-242

48. Giri, K.V., Nagabhushanam, A., Nigam, V. N., and Bolavadi, B. (1955) Science 121, 898-899

49. Petrova, A.N. (1959) Biokhimiya 24, 228-233

50. Peat, S., Whelan, W.J., and Rees, W. (1956) J. Chem. Soc. 44, 44-53

51. Hirschhorn, R. (1995) in The Metabolic and Molecular Bases of Inherited Disease (Schriver, C.R., Beaudet, A.L., Sly, W.S., and Valle, D., eds.) pp. 2443-2464, McGraw Hill, New York

52. Martiniuk, F., Hirschhorn, R., and Smith, M. (1980) Cytogenet. Cell Genet. 27, 168

53. Martiniuk, F., and Hirschhorn, R. (1981) Biochem. Biophys. Acta 658, 248

54. Rodriguez, I.R., and Fliesler, S.J. (1988) Arch. Biochem. Biophys. 206, 628-637

55. Stetten, M.R., Katzen, H.M., and Stetten, D. (1956) J. Biol. Chem. 222, 587-599

56. Lacoste, E.R., Miozzo, M.C., and Curtino, J.A. (1990) Biochem. J. 267, 775-779

57. Lutkic, A., Reipen, W., and Staib, W. (1980) Period. Biolog. 82, 239-250

58. Ercan, N., Gannon, M.C., and Nuttall, F.Q. (1994) J. Biol. Chem. 269, 22328-22333

59. Lomako, J., Lomako, W.M., and Whelan, W.J. (1991) FEBS J. 279, 223-228

60. Lomako, J., Lomako, W.M., Whelan, W.J., Dombro, R.S., Neary, J.T., and Norenberg, M.D. (1993) FASEB J. 7, 1386-1393

61. Smythe, C., Watt, P., and Cohen, P. (1990) Eur. J. Biochem. 189, 199-204

62. Alonso, M.D., Lomako, J., Lomako, W.M., and Whelan, W.J. (1995) FASEB J. 9, 1126-1137

63. Smythe, C., Villar-Palasai, C., and Cohen, P. (1989) Eur. J. Biochem. 183, 205-209

64. Barbetti, F., Rocchi, M., Bossolasco, M., Cordera, R., Sbraccia, P., Finclli, P., and Consalez, G.G. (1996) Biochem. Biophys. Res. Commun. 220, 72-77

Received on February 9, 1996, accepted on April 15, 1996 